\title{
Hasil Skrining Aktivitas Sitotoksik Ekstrak Etanol Daun Kelengkeng (Dimocarpus Longan), Daun Kersen (Muntingia Calabura), dan Daun Alpukat (Persea Americana) terhadap Sel T47D Dan WiDr
}

\section{Cytotoxic Activity Screening of Ethanolic Extract of Longan Leaves (Dimocarpus longan), Jamaican Cherry Leaves (Muntingia calabura), and Avocado Leaves (Persea americana) against T47D dan WiDr Cells}

\author{
Ratna Yuliani*, Broto Santoso, Bella Permatasani, dan Diah Mukti Sari \\ Fakultas Farmasi, Universitas Muhammadiyah Surakarta, Surakarta, Indonesia \\ *E-mail: ratna.yuliani@ums.ac.id
}

Received: 16 Oktober 2019; Accepted: 26 Desember 2019; Published: 27 Desember 2019

\begin{abstract}
Abstrak
Pengobatan kanker biasanya menimbulkan efek yang tidak diinginkan. Oleh karena itu obat antikanker yang aman sangat diperlukan dalam pengobatan kanker. Salah satu sumber obat yang dapat dieksplorasi adalah tanaman. Ekstrak daun kelengkeng (Dimocarpus longan), daun kersen (Muntingia calabura), dan daun alpukat (Persea americana) telah diteliti aktivitas sitotoksiknya terhadap beberapa sel kanker. Penelitian ini bertujuan untuk mengetahui aktivitas sitotoksik ekstrak etanol daun kelengkeng, daun kersen, dan daun alpukat terhadap sel kanker payudara T47D dan sel kanker kolon WiDr serta mengetahui golongan senyawa yang terkandung dalam ekstrak yang mempunyai aktivitas tertinggi. Ekstrak etanol daun kelengkeng, daun kersen, dan daun alpukat diuji aktivitas sitotoksiknya menggunakan metode 3-(4,5-dimetiltiazol-2-il)-2,5difeniltetrazolium bromida (MTT). Identifikasi golongan senyawa di dalam ekstrak etanol daun alpukat dilakukan dengan metode kromatografi lapis tipis menggunakan silika gel $\mathrm{GF}_{254}$ sebagai fase diam dan campuran n-heksan dan aseton (6:4) sebagai fase gerak. Hasil uji sitotoksik menunjukkan bahwa ekstrak etanol daun kelengkeng dan daun kersen sampai konsentrasi $1600 \mu \mathrm{g} / \mathrm{mL}$ tidak mampu menurunkan sel T47D dan WiDr hidup hingga 50\%. Ekstrak daun alpukat dapat menurunkan persentase sel T47D dan WiDr hidup dengan nilai $\mathrm{IC}_{50}$ berturut-turut sebesar $790,679 \mu \mathrm{g} / \mathrm{mL}$ dan 1072,2 $\mu \mathrm{g} / \mathrm{mL}$. Ekstrak etanol daun alpukat mengandung senyawa golongan flavonoid, fenolik, dan terpenoid. Ekstrak etanol daun kelengkeng, daun kersen, dan daun alpukat tidak mempunyai aktivitas sitotoksik terhadap sel kanker payudara T47D dan sel kanker kolon WiDr.

Kata Kunci: antikanker, ekstrak, kelengkeng, kersen, alpukat
\end{abstract}

\begin{abstract}
Cancer treatments usually cause adverse drug reactions. Therefore, safe anticancer drugs are needed in the treatment of cancer. One source of medicine that can be explored is plant. Extracts of longan leaves (Dimocarpus longan), jamaican cherry leaves (Muntingia calabura), and avocado leaves (Persea americana) have been tested for cytotoxic activity against several cancer cell lines. This study aims to determine the cytotoxic activity of ethanolic extract of longan leaves, jamaican cherry leaves, and avocado leaves against T47D and WiDr cells and to identify secondary metabolites in the extracts which have the highest activity. Ethanolic extract of longan leaves, jamaican cherry leaves, and avocado leaves were tested for their cytotoxic activity using the 3-(4,5-dimethylthiazol-2-yl)-2,5-diphenyltetrazolium bromide (MTT) method. Identification of secondary metabolites in the ethanolic extract of avocado leaves was carried out by thin layer chromatography method using silica gel $\mathrm{GF}_{254}$ as the stationary phase and a mixture of $n$-hexane and acetone (6:4) as the mobile phase. Cytotoxic test results show that ethanolic extract of longan leaves and cherry leaves with concentration of up to $1600 \mu \mathrm{g} / \mathrm{mL}$ do not reduce the T47D and WiDr living cells to 50\%. Avocado leaf extract decreases the percentage of living T47D cells and WiDr with $I_{50}$ values of $790.679 \mu \mathrm{g} / \mathrm{mL}$ and $1072.2 \mu \mathrm{g} / \mathrm{mL}$, respectively. The ethanolic extract of avocado leaves contains flavonoid, phenolic, and terpenoid. Ethanolic extract of longan leaves, cherry leaves and avocado leaves do not have cytotoxic activity against T47D and WiDr cells.
\end{abstract}

Keywords: anticancer, extract, longan, jamaican cherry, avocado 


\section{PENDAHULUAN}

Kanker payudara berada pada peringkat atas di antara kanker lain yang diderita oleh perempuan. Kanker payudara pada wanita di dunia menduduki peringkat pertama dengan prevalensi sebesar $6.875 .099 \quad(30,1 \%)$ (Globocan, 2018a) sedangkan angka kematian yang disebabkan oleh kanker tersebut sebanyak 626.060 (15\%) (Globocan, 2018b). Angka kejadian kanker payudara terus meningkat secara global (WHO, 2017). Pada tahun 2013, penderita kanker payudara di Indonesia sebanyak 61.682 (Kemenkes RI, 2015). Di Rumah Sakit Dharmais, dalam rentang tahun 2010-2013 terjadi peningkatan kasus baru kanker payudara dari 711 kasus menjadi 819 kasus dan kematian dari 93 menjadi 217 orang (Kementerian Kesehatan RI, 2015). Selain kanker payudara, kanker kolorektal juga menyebabkan banyak kematian.

Prevalensi kanker kolorektal dan kematian akibat kanker tersebut berada pada posisi ke-2 di antara kanker lain di dunia. Prevalensi kanker kolorektal pada tahun 2018 di seluruh dunia sebesar 4.789 .635 (10,9\%) (Globocan, 2018c) sedangkan angka kematiannya sebesar $880.792 \quad(9,2 \%)$ (Globocan, 2018d). Di Rumah Sakit Dharmais angka kejadian dan kematian akibat kanker kolon meningkat dalam periode 2010-2013. Angka kejadian kanker kolon naik sebanyak 54 kasus sedangkan angka kematian naik sebanyak 21 kematian (Kementerian Kesehatan RI, 2015).

Kanker dapat diobati dengan beberapa cara diantaranya kemoterapi. Pemberian kemoterapi merupakan satu pendekatan manajemen pasien kanker dan hal ini untuk memastikan adanya peningkatan kualitas hidup pasien. Namun kemoterapi dapat menyebabkan adverse drug reactions (ADRs). Beberapa ADRs yang dirasakan oleh pasien kanker di antaranya alopesia (rambut rontok), muntah, konstipasi, anoreksia, merasa lemah, anemia, dan sakit pada persendian (Wahlang et al., 2017). Efek obat yang tidak diinginkan sebaiknya diminimalkan. Salah satu cara untuk mengatasi masalah tersebut adalah mengeksplorasi senyawa alam pada tanaman untuk mendapatkan senyawa dengan aktivitas antikanker yang tinggi tetapi mempunyai efek samping yang rendah.

Aktivitas sitotoksik ekstrak daun kelengkeng telah diteliti terhadap larva udang dan sel kanker. Ekstrak petroleum eter, kloroform, dan etil asetat daun kelengkeng telah diuji aktivitas sitotoksiknya terhadap larva udang (Artemia salina). Ketiga ekstrak tersebut mempunyai kemampuan untuk membunuh larva udang dengan konsentrasi < $13 \mu \mathrm{g} / \mathrm{mL}$. Ekstrak etil asetat mempunyai nilai $\mathrm{LC}_{50}$ yang hanya lebih rendah $3 \mu \mathrm{g} / \mathrm{mL}$ dari nilai $\mathrm{LC}_{50}$ vinkristin sulfat sebagai kontrol positif (Ripa et al., 2010). Ekstrak etanol daun kelengkeng mempunyai aktivitas antiproliferatif terhadap sel WEHI-164 dan THP-1 (Puspita et al., 2019).

Ekstrak dan isolat daun kersen juga telah diuji aktivitas sitotoksiknya terhadap beberapa sel kanker. Nasir et al., (2017) melaporkan bahwa ekstrak metanol daun kersen mempunyai aktivitas antikarsinogenesis yang signifikan terhadap sel kanker kolon tikus. Ekstrak metanol daun kersen juga memiliki antivitas antiproliferatif terhadap beberapa sel dengan $\mathrm{IC}_{50}$ berkisar antara 22 sampai $46 \mu \mathrm{g} / \mathrm{mL}$ (Zakaria et al., 2011). Senyawa 2',4'-dihidroksikalkon dan 5-hidroksi-3,7dimetoksiflavon yang diisolasi dari daun kersen mempunyai aktivitas sitotoksik yang kuat terhadap sel HL60 (Sufian et al., 2013).

Ekstrak etanol daun alpukat yang mengandung senyawa golongan flavonoid, alkaloid, dan saponin mempunyai aktivitas sitotoksik lemah terhadap sel HeLa (Mardiyaningsih dan Ismiyati, 2014).

Berdasarkan kemampuan ekstrak untuk menghambat beberapa sel kanker, penelitian ini menguji aktivitas sitotoksik ekstrak etanol daun kelengkeng, daun kersen, dan daun alpukat terhadap sel kanker payudara T47D dan sel kanker kolon WiDr serta mengidentifikasi golongan senyawa yang 
terkandung di dalam ekstrak dengan aktivitas paling tinggi.

\section{METODE PENELITIAN}

Alat

Alat yang digunakan dalam penelitian ini adalah autoklaf (Hirayama), oven (Memmert), cytoculture cabinet (ESCO), inkubator $\mathrm{CO}_{2}$ (Binder), mikroskop (Olympus), sonikator (Branson 2510), ELISA reader (BioTek), mikropipet (Socorex), hemasitometer, lampu UV 254 nm, dan $366 \mathrm{~nm}$.

\section{Bahan}

Bahan yang digunakan dalam penelitian ini adalah ekstrak etanol daun kelengkeng, daun alpukat, dan daun kersen yang diperoleh dari ekstraksi serbuk daun menggunakan etanol 70\%, akuades, culture flask, conical tube, kertas filter, media Roswell Park Memorial Institute (RPMI), penisilinstreptomisin, fetal bovine serum (FBS), tripsin-EDTA, phosphate buffered saline (PBS), dimetil sulfoksida (DMSO), reagen MTT (3-(4,5-dimetiltiazol-2-il)-2,5 difeniltetrazolium bromida), sodium dodesil sulfat (SDS) $10 \%$ dalam $0,01 \mathrm{~N} \mathrm{HCl}$, etanol 70\%, 96-well plate, microcentrifuge tube, sitroborat, $\mathrm{FeCl}_{3}$, anisaldehid-asam sulfat, nheksan p.a., aseton p.a., dan silika gel $\mathrm{GF}_{254}$.

\section{Uji Sitotoksik}

Sel yang dibutuhkan untuk uji MTT berjumlah $10^{4}$ sumuran. Sel dimasukkan ke dalam tiap sumuran pada 96-well plate dengan volume $100 \mu \mathrm{L}$. Tiga sumuran digunakan untuk kontrol media sehingga tidak diisi sel. Distribusi sel diamati di bawah mikroskop dan hasil pengamatan didokumentasikan. Sel diinkubasi di dalam inkubator $\mathrm{CO}_{2}$ pada suhu $37^{\circ} \mathrm{C}$ sampai sel kembali normal. Setelah inkubasi, media dibuang menggunakan pipet Pasteur. Sebanyak $100 \mu \mathrm{L}$ PBS dimasukkan ke dalam sumuran yang berisi sel, kemudian PBS dibuang menggunakan pipet Pasteur. Ekstrak dalam 5 konsentrasi dimasukkan ke dalam sumuran (triplo). Sel diinkubasi dalam inkubator $\mathrm{CO}_{2}$ pada suhu $37^{\circ} \mathrm{C}$ selama 24 jam.

Pada akhir waktu inkubasi, sel diamati dan didokumentasikan. Media dibuang menggunakan pipet Pasteur lalu reagen MTT $(0,5 \mathrm{mg} / \mathrm{mL})$ sebanyak $100 \mu \mathrm{L}$ dimasukkan ke dalam tiap sumuran termasuk kontrol media. Sel diinkubasi selama 4 jam di dalam inkubator $\mathrm{CO}_{2}$ pada suhu $37^{\circ} \mathrm{C}$. Kondisi sel diamati menggunakan mikroskop. Ketika formazan telah terbentuk dengan jelas, $100 \mu \mathrm{L}$ reagen stopper (SDS 10\% dalam $0,01 \mathrm{~N} \mathrm{HCl}$ ) ditambahkan ke dalam tiap sumuran. Plate dibungkus alumunium foil dan diinkubasi di tempat gelap pada suhu kamar selama semalam. Alumunium foil dan tutup plate dibuka lalu plate dimasukkan ke dalam ELISA reader untuk dibaca serapannya pada panjang gelombang 550.

Serapan kontrol pelarut lebih rendah daripada serapan kontrol sel sehingga persentase sel hidup dihitung dengan persamaan 1 .

$$
\begin{aligned}
& \text { Persentase sel hidup }= \\
& \frac{\text { abs perlakuan-abs kontrol media }}{\text { abs kontrol pelarut-abs kontrol media }} \times 100 \%
\end{aligned}
$$

Grafik log konsentrasi vs persentase sel hidup dibuat dan persamaan regresi linier dihitung. Nilai $\mathrm{IC}_{50}$ dihitung menggunakan persamaan tersebut. Nilai y dimasukkan = $50 \%$ lalu nilai $\mathrm{x}$ dihitung. Jika nilai $\mathrm{x}$ sudah diperoleh, dicari nilai antilognya. Nilai antilog $=$ nilai $\mathrm{IC}_{50}$ (Putri, 2013).

\section{Kromatografi Lapis Tipis}

Kromatografi lapis tipis dilakukan untuk mengetahui golongan senyawa yang terkandung di dalam ekstrak daun yang mempunyai aktivitas sitotoksik tertinggi (ekstrak daun alpukat). Larutan ekstrak dalam etanol ditotolkan pada plat silika gel $\mathrm{GF}_{254}$ lalu dielusi dengan fase gerak campuran n-heksan dan aseton (6:4). Bercak-bercak hasil pemisahan pada plat diamati di bawah sinar tampak, UV $254 \mathrm{~nm}$, dan UV $366 \mathrm{~nm}$. Bercakbercak tersebut disemprot reagen sitroborat, $\mathrm{FeCl}_{3}$, dan anisaldehid-asam sulfat untuk mengidentifikasi golongan senyawa pada tiap bercak. Setelah disemprot dengan sitroborat dan dipanaskan pada suhu $105^{\circ} \mathrm{C}$ selama 5 
Tabel 1. Hasil uji sitotoksik ekstrak etanol daun kelengkeng, daun kersen, dan daun alpukat terhadap sel T47D

\begin{tabular}{cccc}
\hline \multirow{2}{*}{$\begin{array}{c}\text { Konsentrasi } \\
(\mu \mathrm{g} / \mathrm{mL})\end{array}$} & $\begin{array}{c}\text { Ekstrak etanol daun } \\
\text { kelengkeng }\end{array}$ & $\begin{array}{c}\text { Ekstrak etanol daun } \\
\text { kersen }\end{array}$ & $\begin{array}{c}\text { Ekstrak etanol daun } \\
\text { alpukat }\end{array}$ \\
\cline { 2 - 4 } & 104,748 & 112,134 & 105,516 \\
200 & 103,070 & 102,974 & 107,002 \\
400 & 104,988 & 95,300 & 104,029 \\
800 & 110,264 & 58,513 & 30,504 \\
1600 & 68,825 & 50,935 & 22,398 \\
\hline & $\mathrm{IC}_{50}=-$ & $\mathrm{IC}_{50}=-$ & $\mathrm{IC}_{50}=790,679 \mu \mathrm{g} / \mathrm{mL}$ \\
\hline
\end{tabular}

menit, plat diamati di bawah UV $366 \mathrm{~nm}$ sedangkan plat lain diamati di bawah sinar tampak setelah penyemprotan.

\section{HASIL DAN PEMBAHASAN}

Hasil uji sitotoksik ekstrak terhadap sel T47D menunjukkan bahwa ekstrak etanol daun kelengkeng, daun kersen, dan daun alpukat pada konsentrasi $1600 \mu \mathrm{g} / \mathrm{mL}$ mampu menurunkan persentase sel hidup dengan kisaran 31-77\% (Tabel 1). Ekstrak etanol daun alpukat pada konsentrasi $1600 \mu \mathrm{g} / \mathrm{mL}$ mampu menurunkan persentase sel hidup sebanyak 77\% sedangkan ekstrak etanol daun kelengkeng dan daun kersen menyebabkan penurunan persentase sel hidup kurang dari $50 \%$. Hal tersebut mengindikasikan bahwa ekstrak etanol daun alpukat memiliki aktivitas yang paling tinggi dibandingkan dua ekstrak yang lain. Nilai $\mathrm{IC}_{50}$ ekstrak daun kelengkeng dan daun kersen secara pasti tidak dapat dihitung karena pada konsentrasi tertinggi yang diujikan ekstrak belum dapat menurunkan persentase sel hidup hingga $50 \%$. Ekstrak etanol daun alpukat memiliki nilai $\mathrm{IC}_{50}$ sebesar 790,679 $\mu \mathrm{g} / \mathrm{mL}$. Srisawat et al. (2013) mengkategorikan aktivitas sitotoksik menjadi 4 yaitu $\mathrm{IC}_{50} \leq 20 \mu \mathrm{g} / \mathrm{mL}$ tergolong sangat aktif, $\mathrm{IC}_{50}$ antara 21 sampai $200 \mu \mathrm{g} / \mathrm{mL}$ tergolong sedang, $\mathrm{IC}_{50}$ antara 201 sampai 500 $\mu \mathrm{g} / \mathrm{mL}$ tergolong lemah, dan $\mathrm{IC}_{50}>500 \mu \mathrm{g} / \mathrm{mL}$ tergolong tidak aktif. Berdasarkan kategori tersebut, ekstrak etanol daun alpukat tergolong tidak aktif atau tidak mempunyai aktivitas sitotoksik terhadap sel T47D. Doksorubisin yang diujikan pada sel T47D sebagai kontrol positif mempunyai aktivitas sitotoksik terhadap dengan nilai IC $_{50}$ sebesar $57,677 \mu \mathrm{g} / \mathrm{mL}$ (Tabel 2).

Tabel 2. Hasil uji sitotoksik doksorubisin terhadap sel T47D

\begin{tabular}{ccc}
\hline $\begin{array}{c}\text { Konsentrasi } \\
(\mu \mathrm{g} / \mathrm{mL})\end{array}$ & $\begin{array}{c}\text { Sel T47D } \\
\text { hidup }(\%)\end{array}$ & $\begin{array}{c}\mathrm{IC}_{50} \\
(\mu \mathrm{g} / \mathrm{mL})\end{array}$ \\
\hline 6,25 & 58,657 & \\
12,5 & 54,197 & \\
25 & 56,115 & 57,677 \\
50 & 48,489 & \\
100 & 48,393 & \\
\hline
\end{tabular}

Hasil uji sitotoksik ekstrak etanol daun kelengkeng, daun kersen, dan daun alpukat terhadap sel WiDr menunjukkan bahwa tiap ekstrak menunjukkan aktivitas yang tidak sama. Ekstrak daun kelengkeng, daun kersen, dan daun alpukat dengan konsentrasi 1600 $\mu \mathrm{g} / \mathrm{mL}$ mampu menurunkan persentase sel hidup berturut-turut sebesar 6,603\%, 23,450\%, dan 70,877\% (Tabel 3). Hasil tersebut menunjukkan bahwa ekstrak daun alpukat mempunyai aktivitas yang paling tinggi dibandingkan ekstrak daun kelengkeng dan kersen. Nilai IC $_{50}$ ekstrak daun alpukat terhadap sel WiDr sebesar 1072,2 $\mu \mathrm{g} / \mathrm{mL}$ sedangkan nilai $\mathrm{IC}_{50}$ ekstrak daun kelengkeng dan kersen tidak dihitung karena ekstrak tidak mampu menghambat pertumbuhan sel WiDr hingga 50\%. Ekstrak etanol daun alpukat tergolong tidak aktif karena mempunyai nilai $\mathrm{IC}_{50}$ lebih dari $500 \mu \mathrm{g} / \mathrm{mL}$. Doksorubisin sebagai kontrol positif mempunyai aktivitas sitotoksik yang kuat terhadap sel WiDr 
Tabel 3. Hasil uji sitotoksik ekstrak etanol daun kelengkeng, daun kersen, dan daun alpukat terhadap sel WiDr

\begin{tabular}{cccc}
\hline \multirow{2}{*}{$\begin{array}{c}\text { Konsentrasi } \\
(\mu \mathrm{g} / \mathrm{mL})\end{array}$} & $\begin{array}{c}\text { Ekstrak etanol daun } \\
\text { kelengkeng }\end{array}$ & $\begin{array}{c}\text { Ekstrak etanol daun } \\
\text { kersen }\end{array}$ & $\begin{array}{c}\text { Ekstrak etanol daun } \\
\text { alpukat }\end{array}$ \\
\hline 100 & 101,377 & 108,453 & 110,020 \\
200 & 106,693 & 106,693 & 111,347 \\
400 & 102,303 & 97,870 & 85,193 \\
800 & 99,870 & 96,543 & 63,473 \\
1600 & 93,397 & 76,550 & 29,123 \\
\hline & $\mathrm{IC}_{50}=-$ & $\mathrm{IC}_{50}=-$ & $\mathrm{IC}_{50}=1072,2 \mu \mathrm{g} / \mathrm{mL}$ \\
\hline
\end{tabular}

dengan nilai $\mathrm{IC}_{50}$ sebesar $2,29 \mu \mathrm{g} / \mathrm{mL}$ (Tabel 4).

Tabel 4. Hasil uji sitotoksik doksorubisin terhadap sel WiDr

\begin{tabular}{ccc}
\hline $\begin{array}{c}\text { Konsentrasi } \\
(\mu \mathrm{g} / \mathrm{mL})\end{array}$ & $\begin{array}{c}\text { Sel WiDr } \\
\text { hidup }(\%)\end{array}$ & $\begin{array}{c}\mathrm{IC}_{50} \\
(\mu \mathrm{g} / \mathrm{mL})\end{array}$ \\
\hline 0,78125 & 56,427 & \\
1,5625 & 49,333 & \\
3,125 & 46,277 & 2,29 \\
6,25 & 51,103 & \\
12,5 & 39,890 & \\
\hline
\end{tabular}

Nilai IC $_{50}$ yang sangat jauh berbeda antara ekstrak dan doksorubisin baik pada uji terhadap sel T47D maupun WiDr menunjukkan perbedaan sitotoksisitas di antara kedua bahan. Nilai $\mathrm{IC}_{50}$ menunjukkan konsentrasi yang dapat menurunkan persentase sel hidup sebanyak 50\% sehingga semakin kecil nilai $\mathrm{IC}_{50}$ semakin toksik suatu bahan terhadap sel. Dalam penelitian ini, doksorubin mempunyai aktivitas sitotoksik yang jauh lebih tinggi dibandingkan ekstrak karena doksorubisin merupakan senyawa tunggal yang telah terbukti aktivitas sitotoksiknya sedangkan ekstrak masih mengandung banyak senyawa yang kemungkinan tidak semuanya mempunyai aktivitas sitotoksik. Menurut National Cancer Institute (n.d.b), doksorubisin merupakan antibiotik antrasiklin yang mempunyai aktivitas antineoplastik dengan cara menyisip di antara pasangan DNA sehingga mencegah replikasi DNA. Senyawa tersebut juga menghambat enzim topoisomerase II sehingga penggabungan untai nukleotida tidak terjadi. Selain mekanisme aksi tersebut, doksorubisin dapat membentuk radikal bebas oksigen yang menghasilkan efek sitotoksik sekunder terhadap peroksidasi lipid di membran sel.

Hasil uji sitotoksik ekstrak etanol daun kelengkeng, daun kersen, dan daun alpukat menunjukkan bahwa ekstrak tidak mempunyai potensi sitotoksik terhadap sel T47D dan WiDr. Penelitian lain mampu menemukan ekstrak yang sangat toksik terhadap sel kanker. Ekstrak metanol seluruh bagian tanaman Elephantopus mollis dan daun Kalanchoe crenata mempunyai aktivitas yang tinggi terhadap sel kanker payudara MCF-7 dengan nilai $\mathrm{IC}_{50}$ berturut-turut sebesar 3,97 \pm $0,48 \mu \mathrm{g} / \mathrm{mL}$ dan $19,31 \pm 0,79 \mu \mathrm{g} / \mathrm{mL}$ (Kuete et al., 2017). Ekstrak metanol dan aseton kotiledon buah Vatica diospyroides tipe LS bersifat sangat toksik terhadap sel kanker payudara MDA-MB-468 dengan nilai $\mathrm{IC}_{50}$ sebesar 3,1 $\mu \mathrm{g} / \mathrm{mL}$ sedangkan ekstrak diklorometan perikarpnya mempunyai IC $_{50}$ sebesar 18,2 $\mu \mathrm{g} / \mathrm{mL}$ terhadap sel MCF-7 (Srisawat et al., 2013). Alima dan Demayo (2018) menyatakan bahwa ekstrak etanol daun Canarium ovatum dan Pangium edule mempunyai aktivitas sitotoksik yang tinggi terhadap sel karsinoma kolon dengan nilai $\mathrm{IC}_{50}$ berturut-turut sebesar $4,39 \pm 0,59 \mu \mathrm{g} / \mathrm{mL}$ dan $5,40 \pm 1,56 \mu \mathrm{g} / \mathrm{mL}$.

Hasil penelitian ini berbeda dengan penelitian lain yang menyatakan bahwa daun kelengkeng, daun kersen, dan daun alpukat mempunyai potensi sitotoksik terhadap beberapa sel kanker. Hasil uji sitotoksik daun 
kelengkeng yang berbeda teramati pada penelitian lain. Ekstrak etanol daun kelengkeng pada konsentrasi $400 \mu \mathrm{g} / \mathrm{mL}$ mampu menghambat proliferasi sel WEHI164 dan THP-1 sebesar 39,13\% dan 51,06\% (Puspita et al., 2019). Jika hasil tersebut dibandingkan dengan hasil penelitian ini, ekstrak daun kelengkeng dengan konsentrasi yang sama tidak mampu menurunkan persentase sel T47D dan WiDr hidup. Perbedaan hasil tersebut kemungkinan disebabkan oleh perbedaan sel yang digunakan untuk uji. Sel yang berbeda kemungkinan mempunyai sensitivitas yang berbeda sehingga ketahanan untuk dihambat oleh ekstrak juga berbeda. Dalam hal ini sel WEHI-164 dan THP-1 kemungkinan lebih sensitif terhadap ekstrak daun kelengkeng daripada sel T47D dan WiDr.

Uji sitotoksik daun kersen dari beberapa penelitian juga menunjukkan hasil yang tidak sama. Pada penelitian ini ekstrak daun kersen tidak menunjukkan aktivitas sitotoksik terhadap sel T47D dan WiDr tetapi pada penelitian lain daun kersen terbukti aktif sebagai antikanker. Ekstrak metanol daun kersen dari Malaysia mempunyai aktivitas antikarsinogenesis pada kanker kolon tikus yang diinduksi azoksimetan (Nasir et al., 2017). Zakaria et al. (2011) juga melaporkan aktivitas antiproliferatif ekstrak metanol daun kersen terhadap sel MCF-7, HeLa, HT-29, HL-60, dan K-562. Senyawa krisin dan 5,7dihidroksi-8-metoksiflavonol yang diisolasi dari daun kersen berpotensi sitotoksik terhadap beberapa sel kanker manusia dengan nilai $\mathrm{ED}_{50}<20 \mu \mathrm{g} / \mathrm{mL}$ (Nshimo et al., 1993). Perbedaan sel, tempat tumbuh tanaman, dan bahan yang diuji diduga menyebabkan perbedaan hasil di antara penelitian tersebut. Sel yang berbeda kemungkinan mempunyai perbedaan sensivititas terhadap bahan uji. Perbedaan tempat tumbuh tanaman dapat menyebabkan perbedaan senyawa metabolit sekunder yang diproduksi (Juane et al., 2011) sehingga aktivitas farmakologinya tidak sama. Senyawa yang digunakan oleh Nshimo et al. (1993) merupakan senyawa tunggal hasil isolasi sehingga aktivitasnya lebih tinggi dibandingkan ekstrak yang masih mengandung campuran senyawa.

Hasil penelitian ekstrak daun alpukat terhadap sel T47D dan WiDr berbeda dengan hasil uji terhadap sel lain. Ekstrak metanol daun alpukat mempunyai sifat sitotoksik yang sedang terhadap sel HepG-2, HT-29, dan MCF-7 dengan penghambatan berturut-turut sebesar 73,6\%, 64,5\%, dan 51,2\% (Khalifa et al., 2013). Mardiyaningsih dan Ismiyati (2014) melaporkan bahwa ekstrak etanol daun alpukat mampu menghambat pertumbuhan sel HeLa dengan nilai $\mathrm{IC}_{50}$ sebesar $360 \mu \mathrm{g} / \mathrm{mL}$. Perbedaan hasil uji sitotoksik dari beberapa penelitian kemungkinan besar disebabkan oleh perbedaan sel yang digunakan karena setiap sel mempunyai kepekaan yang tidak sama terhadap zat yang diujikan.

Hasil uji sitotoksik menunjukkan bahwa ekstrak etanol daun alpukat memiliki aktivitas sitotoksik paling tinggi di antara ekstrak yang diuji. Oleh karena itu, kandungan senyawa di dalam ekstrak etanol daun alpukat diidentifikasi dengan metode KLT menggunakan reagen semprot sitroborat, anisaldehid-asam sulfat, dan $\mathrm{FeCl}_{3}$. Sitroborat digunakan untuk mengidentifikasi adanya flavonoid di dalam ekstrak yang ditandai dengan fluoresensi bercak yang berwarna kuning kehijauan di bawah UV $366 \mathrm{~nm}$ setelah disemprot dan dipanaskan dalam oven. Anisaldehid-asam sulfat dapat mengidentifikasi senyawa terpenoid yang berwarna ungu setelah penyemprotan. $\mathrm{FeCl}_{3}$ dapat digunakan untuk mendeteksi fenol yang ditandai salah satunya dengan terbentuknya warna hitam pada bercak. Hasil uji KLT menunjukkan bercak-bercak hasil elusi memberikan reaksi positif terhadap reagen semprot sehingga dapat disimpulkan bahwa ekstrak daun alpukat mengandung flavonoid, terpenoid, dan fenolik (Gambar 1).

Hasil identifikasi senyawa yang terkandung dalam daun alpukat pada penelitian ini tidak sama dengan hasil penelitian lain. Mardiyaningsih dan Ismiyati (2014) melaporkan bahwa ekstrak etanolik 


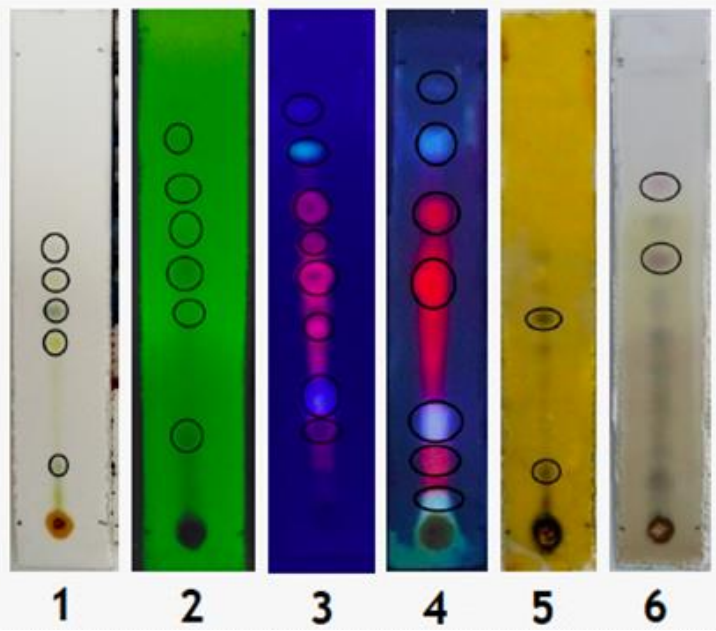

Keterangan:

1. Lempeng diamati di bawah sinar tampak

2. Lempeng diamati di bawah sinar UV $254 \mathrm{~nm}$

3. Lempeng diamati di bawah sinar UV $366 \mathrm{~nm}$

4. Lempeng disemprot sitroborat dan diamati di bawah sinar UV $366 \mathrm{~nm}$

5. Lempeng disemprot $\mathrm{FeCl}_{3}$ dan diamati di bawah sinar tampak

6. Lempeng disemprot anisaldehidasam sulfat dan diamati di bawah sinar tampak

Gambar 1. Hasil kromatografi lapis tipis ekstrak etanol daun alpukat dengan fase diam silika gel GF254 dan fase gerak campuran n-heksan dan aseton dengan perbandingan 6:4

daun alpukat mengandung alkaloid, flavonoid, dan saponin. Dalam penelitian tersebut alkaloid dan saponin terdeteksi dalam ekstrak etanol daun alpukat tetapi tidak terdeteksi pada penelitian ini. Perbedaan tersebut kemungkinan disebabkan oleh perbedaan reagen semprot yang digunakan. Penelitian ini tidak menggunakan reagen Dragendorff dan vanilin-asam sulfat ini sehingga senyawa alkaloid dan saponin tidak teridentifikasi.

Walaupun ekstrak daun alpukat mengandung metabolit sekunder flavonoid, terpenoid, dan fenolik tetapi ekstrak tidak mempunyai aktivitas sitotoksik terhadap sel T47D dan sel WiDr. Kemungkinan senyawasenyawa yang terkandung di dalam ekstrak tidak mempunyai target aksi pada sel atau sel yang digunakan tidak sensitif terhadap senyawa-senyawa yang terkandung di dalam ekstrak sehingga ekstrak tidak mampu menghambat pertumbuhan sel T47D dan WiDr.

\section{KESIMPULAN}

Dari hasil penelitian ini dapat disimpulkan bahwa ekstrak etanol daun kelengkeng, daun kersen, dan daun alpukat tidak bersifat sitotoksik terhadap sel T47D dan WiDr. Ekstrak etanol daun alpukat mengandung flavonoid, fenolik, dan terpenoid.

\section{Daftar Pustaka}

Alima, Z. dan Demayo, C.G., 2018. Antioxidant and Cytotoxic Activities of Selected Plant Extracts Against Human Non-Small Cell Lung Adenocarcinoma (A549), Human Colon Carcinoma Cells (HCT116) and Chinese Hamster Normal Ovary Cells (AA8). International Journal of Pharmaceutical Sciences and Research, 9(11), pp. 4562-4571.

Globocan, 2018a. Estimated Number of Prevalent Cases (5-year) in 2018, Worldwide, All Cancers, Females, All Ages, [online], Terdapat di: http://gco.iarc.fr/today/online-analysispie $? \mathrm{v}=2018 \&$ mode $=$ cancer $\&$ mode $\_$population $=$continents \&population $=900 \&$ population

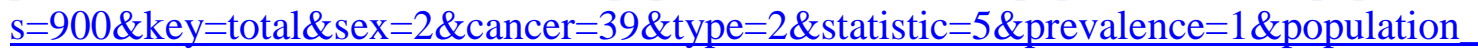
group $=0 \&$ ages_group $\% 5 \mathrm{~B} \% 5 \mathrm{D}=0 \&$ ages_group $\% 5 \mathrm{~B} \% 5 \mathrm{D}=17 \& \mathrm{nb}$ items $=7 \&$ group_can cer $=1 \&$ include $n m s c=1 \&$ include $n m s c$ other $=1 \&$ half_pie $=0 \&$ donut $=0 \&$ population_gr 
oup_globocan_id= (diakses pada 15 Agustus 2019).

Globocan, 2018b. Estimated Number of Deaths in 2018 Worldwide, All Cancesr, Females, All Ages, [online], Terdapat di: http://gco.iarc.fr/today/online-analysispie $? \mathrm{v}=2018 \&$ mode $=$ cancer $\&$ mode $\_$population $=$continents $\&$ population $=900 \&$ population

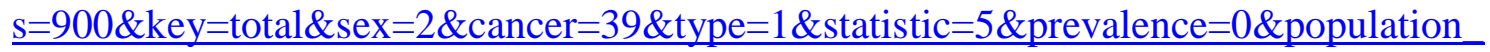
group $=0 \& a g e s \_g r o u p \% 5 \mathrm{~B} \% 5 \mathrm{D}=0 \&$ ages_group $\% 5 \mathrm{~B} \% 5 \mathrm{D}=17 \& \mathrm{nb}$ items $=7 \&$ group_can $\underline{\text { cer }=1 \text { \&include } n m s c}=1$ \&include $n$ nmsc other $=1$ \&half_pie $=0 \&$ donut $=0$ \&population_gr oup_globocan_id= (diakses pada 15 Agustus 2019).

Globocan, 2018c. Estimated Number of Prevalent Cases (5-year) in 2018, Worldwide, All Cancers, Both Sexes, All Ages, [online], Terdapat di: http://gco.iarc.fr/today/onlineanalysis-

pie $? \mathrm{v}=2018 \&$ mode $=$ cancer\&mode $\_$population $=$continents\&population=900\&population

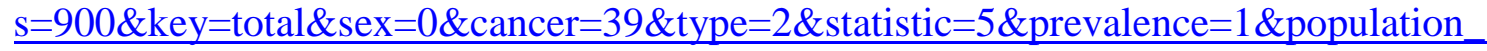
group $=0 \&$ ages_group $\% 5 \mathrm{~B} \% 5 \mathrm{D}=0 \&$ ages group $\% 5 \mathrm{~B} \% 5 \mathrm{D}=17 \& \mathrm{nb}$ items $=7 \&$ group_can $\underline{\text { cer }=1 \& \text { include } \_n m s c}=1 \&$ include $n$ msc other $=1 \&$ half_pie $=0 \&$ donut $=0$ \&population_gr oup_globocan_id= (diakses pada 16 Agustus 2019).

Globocan, 2018d. Estimated Number of Death in 2018, Worldwide, All Cancers, Both Sexes, All Ages, [online], Terdapat di: http://gco.iarc.fr/today/online-analysispie $? \mathrm{~V}=2018 \&$ mode $=$ cancer $\&$ mode population $=$ continents\&population $=900 \&$ population

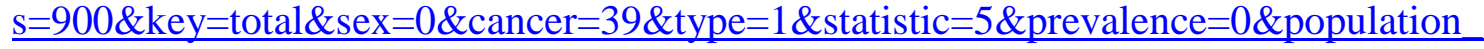
group $=0 \&$ ages group $\% 5 \mathrm{~B} \% 5 \mathrm{D}=0 \&$ ages group $\% 5 \mathrm{~B} \% 5 \mathrm{D}=17 \& \mathrm{nb}$ items $=7 \&$ group can $\underline{\text { cer }=1 \& \text { include } n m s c}=1 \&$ include_nmsc_other $=1 \&$ half_pie $=0 \&$ donut $=0 \&$ population_gr oup_globocan_id= (diakses pada 16 Agustus 2019).

Juane, D., Xihan, M., Qin, W., Shaobing, P., Shechao, Z., 2011. Effects of Growing Location on the Contents of Secondary Metabolites in the Leaves of Four Selected Superior Clones of Eucommia ulmoides. Industrial Crops and Products, 34(3), pp. 1607-1614.

Kementerian Kesehatan RI, 2015. Stop Kanker. InfoDATIN, pp. 1-6.

Khalifa, N.S., El-Hallouty, S.M., Barakat, H.S., dan Salim, D.M., 2013. In Vitro Cytotoxic and Antioxidant Activities of Some Plant Extract on Different Human Cancer Cell Lines. The Egyptian Journal of Experimental Biology (Botany), 9(1), pp. 137-144.

Kuete, V., Fokou, F.W., Karaosmanoglu, O., Beng, V.P., dan Sivas, H., 2017. Cytotoxicity of the Methanol Extracts of Elephantopus mollis, Kalanchoe crenata and 4 Other Cameroonian Medicinal Plants Towards Human Carcinoma Cells. BMC Complementary and Alternative Medicine, 17(280), pp. 1-9.

Mardiyaningsih, A. dan Ismiyati, N., 2014. Aktivitas Sitotoksik Ekstrak Etanolik Daun Alpukat (Persea americana Mill.) pada Sel Kanker Leher Rahim HeLa, Traditional Medicine Journal, 19(1), pp. 24-28.

Nasir, N.L.Md., Kamsani, N.E., Mohtarrudin, N., Othman, F., Tohid, S.F.Md., dan Zakaria, Z.A., 2017. Anticarcinogenic Activity of Muntingia calabura Leaves Methanol Extract Against The Azoxymethane-induced Colon Cancer in Rats Involved Modulation of The Colonic Antioxidant System Partly by Flavonoids. Pharmaceutical Biology, 55(1), pp. 2102-2109.

National Cancer Institute, n.d.b. Doxorubicin (Code C456), (online), Terdapat di: https://ncit.nci.nih.gov/ncitbrowser/ConceptReport.jsp?dictionary=NCI_Thesaurus\&ns= 
$\underline{\text { NCI Thesaurus \& code }=C 456}$ [diakses pada 16 Agustus 2019).

Nshimo, C.M., Pezzuto, J.M., Kinghorn, A.D., dan Farnsworth, N.R., 1993. Cytotoxic Constituent of Muntingia calabura Leaves and Stems Collected in Thailand. International Journal of Pharmacognosy, 31, pp. 77-81.

Puspita, R., Bintang, M., dan Priosoeryanto, B.P., 2019. Antiproliferative Activity of Longan (Dimocarpus longan Lour.) Leaf Extracts, Journal of Applied Pharmaceutical Science, 9(05), pp. 102-106.

Putri, H., 2013. Protokol: Uji Sitotoksik Metode MTT, Cancer Chemoprevention Research Center, Fakultas Farmasi, UGM.

Ripa, F.A., Haque, M., dan Bulbul, I.J., 2010. In Vitro Antibacterial, Cytotoxic and Antioxidant Activities of Plant Nephelium longan. Pakistan Journal of Biological Sciences, 13(1), pp. 22-27.

Srisawat, T., Chumkaew, P., Heed-Chim, W., Sukpondma, Y., dan Kanokwiroon, K., 2013. Phytochemical Screening and Cytotoxicity of Crude Extracts of Vatica diospyroides Symingron Type LS. Tropical Journal of Pharmaceutical Research, 12(1), pp. 71-76.

Sufian, A.S., Ramasamy, K., Ahmat, N, Zakaria, Z.A., dan Yusof, M.I.M., 2013. Isolation and Identification of Antibacterial and Cytotoxic Compounds from The Leaves of Muntingia calabura L.. Journal of Ethnopharmacology, 146, pp. 198-204.

Wahlang, J.B., Lashram, P.D., Brahma, D.K., Sarkar, C., Lahon, J., dan Nongkynrih, B.S., 2017. Adverse Drug Reactions Due to Cancer Chemotherapy in A Tertiary Care Teaching Hospital. Therapeutic Advances in Drug Safety, 8(2), pp. 61-66.

WHO, 2017. Breast Cancer, Terdapat di http://www.who.int/cancer/prevention/diagnosisscreening/breast-cancer/en/ [diakses pada 1 November 2017].

Zakaria, Z.A., Mohamed, A.M., Jamil, N.S.M., Rofiee, M.S., Hussain, M.K., Sulaiman, M.R., The, L.K., dan Salleh, M.Z., 2011. In Vitro Antiproliferative and Antioxidant Activities of the Extracts of Muntingia calabura Leaves. American Journal of Chinese Medicine, 39(1), pp. 183-200. 